\title{
Combined effects of warming and ocean acidification on coral reef Foraminifera Marginopora vertebralis and Heterostegina depressa
}

\author{
Christiane Schmidt • Michal Kucera • \\ Sven Uthicke
}

Received: 4 October 2013/Accepted: 2 April 2014/Published online: 19 April 2014

(C) The Author(s) 2014. This article is published with open access at Springerlink.com

\begin{abstract}
Warming and changes in ocean carbonate chemistry alter marine coastal ecosystems at an accelerating pace. The interaction between these stressors has been the subject of recent studies on reef organisms such as corals, bryozoa, molluscs, and crustose coralline algae. Here we investigated the combined effects of elevated sea surface temperatures and $p \mathrm{CO}_{2}$ on two species of photosymbiont-bearing coral reef Foraminifera: Heterostegina depressa (hosting diatoms) and Marginopora vertebralis (hosting dinoflagellates). The effects of single and combined stressors were studied by monitoring survivorship, growth, and physiological parameters, such as respiration, photochemistry (pulse amplitude modulation fluorometry and oxygen production), and chl $a$ content. Specimens were exposed in flow-through aquaria for up to seven weeks to combinations of two $p \mathrm{CO}_{2} \quad(\sim 790$ and $\sim 490 \mu \mathrm{atm})$ and two temperature $\left(28\right.$ and $\left.31^{\circ} \mathrm{C}\right)$ regimes. Elevated temperature had negative effects on the physiology of both species. Elevated $p \mathrm{CO}_{2}$ had negative effects on growth and apparent photosynthetic rate in H.depressa but a positive effect on effective quantum yield. With increasing $p \mathrm{CO}_{2}$, chl $a$ content decreased in $H$. depressa
\end{abstract}

Communicated by Biology Editor Dr. Anastazia Banaszak

Electronic supplementary material The online version of this article (doi:10.1007/s00338-014-1151-4) contains supplementary material, which is available to authorized users.

C. Schmidt $(\bowtie) \cdot$ M. Kucera

MARUM, University of Bremen, Leobener Str., 28359 Bremen,

Bremen, Germany

e-mail: cschmidt@marum.de

S. Uthicke

Australian Institute of Marine Science, PMB No 3, Townsville, QLD, Australia and increased in $M$. vertebralis. The strongest stress responses were observed when the two stressors acted in combination. An interaction term was statistically significant in half of the measured parameters. Further exploration revealed that $75 \%$ of these cases showed a synergistic (= larger than additive) interaction between the two stressors. These results indicate that negative physiological effects on photosymbiont-bearing coral reef Foraminifera are likely to be stronger under simultaneous acidification and temperature rise than what would be expected from the effect of each of the stressors individually.

Keywords Climate change - Ocean acidification . Benthic Foraminifera · Diatoms · Dinoflagellates · Symbiosis

\section{Introduction}

Coral reef ecosystems react sensitively to rapid climatic events and changes in ocean carbonate chemistry (HoeghGuldberg et al. 2007; Wernberg et al. 2013). It is increasingly acknowledged that an understanding of the effect of these stressors on marine organisms requires experiments investigating the combined effects of multiple stressors. In theory, when the stressors individually have a negative effect, then their combined effect can be either additive (total effect $C=A+B$ ), antagonistic $(C<A+$ $B$ ), or synergistic $(C>A+B)$ (Crain et al. 2008). In the context of global change, it is especially important to understand whether synergistic effects are likely to occur under the combination of stressors. Interactive effects of warming and rising $p \mathrm{CO}_{2}$ have been observed in marine organisms, such as corals, bryozoa, molluscs, and crustose coralline algae (Reynaud et al. 2003; Anthony et al. 2008; 
Rodolfo-Metalpa et al. 2010, 2011). A meta-analysis of a decade of climate change experiments on marine organisms indicated that environmental stressors can have significant combined effects, often not detectable in singlestressor studies (Wernberg et al. 2012). The negative effects of raised $p \mathrm{CO}_{2}$ are amplified by simultaneously elevated temperatures in marine crustose coralline algae and macroalgae, but indicate that the response to the combined treatment is species specific (Martin and Gattuso 2009; Koch et al. 2013). In contrast, McCulloch et al. (2012) showed that increasing temperature may counteract the negative effects of acidification on calcification in corals, by facilitating upregulation of $\mathrm{pH}$ at the site of calcification. Collectively, these studies illustrate that coral reef organisms exhibit significant interactive effects in response to key global change stressors, but the strength and direction of response differ among taxa.

Pörtner $(2002,2008)$ argued that protists and especially prokaryotes might be less vulnerable to $p \mathrm{CO}_{2}$ and temperature stress than more complex macro-organisms because the latter are more specialised on a molecular level. An ecologically significant group of protists on coral reefs are benthic Foraminifera. Foraminifera are major ecosystem engineers in coral reefs because they contribute significantly to the carbonate sediment production (Langer et al. 1997), providing substrata for other coral reef organisms. Larger Foraminifera host photosymbionts, which facilitate growth to cell sizes 10-100 times larger than their asymbiotic relatives (Hallock 1985; Lee and Hallock 1987; Lee 1995). The endosymbiosis is sensitive to thermal and light stress, leading to bleaching analogous to that in corals (Hallock et al. 1992; Hallock and Talge 1993). The effect of thermal stress in Foraminifera has been documented in laboratory studies (Talge and Hallock 2003; Schmidt et al. 2011; Uthicke et al. 2011). In the field, thermal pollution was documented to effect foraminiferal species composition (Arieli et al. 2011).

The effect of changes in ocean carbonate chemistry on Foraminifera due to raised $p \mathrm{CO}_{2}$ levels in the atmosphere is not yet fully understood. Experimental manipulations of various species of Foraminifera using $p \mathrm{CO}_{2}$ levels of up to 2,000 $\mu$ atm have shown no evidence for reduced survivorship (McIntyre-Wressnig et al. 2013), nor any effects on photobiology and calcification (Vogel and Uthicke 2012), supporting the hypothesis of Pörtner (2002, 2008). Other studies, however, have shown reduced calcification of coral reef Foraminifera at elevated $p \mathrm{CO}_{2}$ levels (Kuroyanagi et al. 2009; Haynert et al. 2011; Reymond et al. 2013). Fujita et al. (2011) reported that calcification in two tropical Foraminifera hosting diatoms and exhibiting a hyaline shell increased with elevated $p \mathrm{CO}_{2}$ up to $770 \mu$ atm and decreased at $p \mathrm{CO}_{2}$ levels up to $970 \mu \mathrm{atm}$. One species with a porcelaneous shell decreased in size with increasing $p \mathrm{CO}_{2}$. Species-specific responses have been confirmed in a study by Hikami et al. (2011). Studies of Foraminifera from natural $\mathrm{CO}_{2}$ seeps with locally decreased $\mathrm{pH}$ reported increasing incidences of altered shell structure, decreasing population densities, declining diversity in calcifying Foraminifera, and increasing proportion of Foraminifera with agglutinated shells towards low $\mathrm{pH} /$ high $p \mathrm{CO}_{2}$ (Dias et al. 2010; Fabricius et al. 2011; Uthicke and Fabricius 2012; Uthicke et al. 2013). Test dissolution has been reported under elevated $p \mathrm{CO}_{2}$ (Sinutok et al. 2011).

Interactive effects of elevated $p \mathrm{CO}_{2}$ and eutrophication have been shown to impact growth in Marginopora rossi (Reymond et al. 2013). Elevated temperatures and eutrophication can also have interactive negative effects on growth and survivorship in Marginopora vertebralis (Uthicke et al. 2011). Negative effects of elevated temperatures are more severe in the presence of low concentrations of the herbicide Diuron (van Dam et al. 2012).

The main aim of this study was to investigate the individual effects of $p \mathrm{CO}_{2}$ and temperature and their combined effects on coral reef Foraminifera. In particular, we aimed to gain a better understanding of parameters targeting the foraminiferal photosymbionts (photosynthesis, oxygen production, and chl $a$ content) and the holobiont (survivorship, respiration, and growth) in response to a combination of stressors. The multi-factorial experiment consisted of two $p \mathrm{CO}_{2}$ levels ( $\mathrm{pH} 7.9$ and 8.1) and two temperature levels $\left(28\right.$ and $\left.31{ }^{\circ} \mathrm{C}\right)$. The elevated treatments $\left(31^{\circ} \mathrm{C}\right.$ and $\left.\mathrm{pH} 7.9\right)$ simulate levels that are predicted to occur by the end of the century in Australian coastal waters (Lough and Hobday 2011; Redondo-Rodriguez et al. 2012). Since investigations of multiple stressors on other marine organisms showed significant differences among taxa, the experiment included two species of Foraminifera. Heterostegina depressa and $M$. vertebralis represent two phylogenetically distinct clades that appear to have diverged >500 million years ago, evolved calcification independently of each other (Pawlowski et al. 2003) and host different types of photosymbionts (Lee 2006).

\section{Materials and methods}

Species selection and sample collection

Two species of Foraminifera were investigated: $M$. vertebralis and $H$. depressa. $M$. vertebralis represents the family Soritidae, which produces imperforate, porcelaneous tests made of high-Mg calcite (Blackmon and Todd 1959). This species is abundant in shallow reef settings of the Indo-Pacific Ocean (Langer and Lipps 2003). It harbours dinoflagellate symbionts of the genus Symbiodinium 
(Pochon et al. 2007; Momigliano and Uthicke 2013). $H$. depress $a$ is a representative of the family Nummulitidae, which produces multi-layered, perforate low Mg-calcite tests and harbours endosymbiotic diatoms (Lee et al. 1980; Leutenegger 1984). This species occurs in highest abundance below $10-\mathrm{m}$ water depth and is less abundant in highly energetic shallow habitats (Hohenegger et al. 1999; Renema 2006; Nobes et al. 2008). Specimens were collected from Orpheus Island in the central Great Barrier Reef in September 2011. H. depressa was collected at a depth of 8-12 m from coral rubble (Cattle Bay, $18^{\circ} 34^{\prime} 08^{\prime \prime} \mathrm{S}$ $146^{\circ} 28^{\prime} 55^{\prime \prime} \mathrm{E}$ ) and $M$. vertebralis at a depth of $0-1 \mathrm{~m}$ (below Lowest Astronomical Tide) from turf algae-covered rocks (Hazard Bay, 18 $38^{\prime} 58^{\prime \prime} \mathrm{S} 146^{\circ} 29^{\prime} 11^{\prime \prime} \mathrm{E}$ ). Both species were acclimated to laboratory conditions in tanks with moderate flow-through conditions (same as used in experimental setup) under low-light conditions (10 $\mu \mathrm{mol}$ photons $\mathrm{m}^{-2} \mathrm{~s}^{-1}$ ) for a period of 3 weeks.

Experimental design and carbonate system parameters

12 flow-through aquaria (working volume $17.5 \mathrm{~L}$ ) were installed in a constant temperature room, and the experiment was carried out over a period of $53 \mathrm{~d}$. The duration of experimental exposure was adapted to the species' biological response in order to perform final respiration and production measurements on all treatments. The exposure time of $53 \mathrm{~d}$ for $M$. vertebralis and $35 \mathrm{~d}$ for $H$. depressa was deemed adequate to observe the effects of long-term stress. For each temperature $\left(28\right.$ and $\left.31{ }^{\circ} \mathrm{C}\right)$ and $p \mathrm{CO}_{2}$ level ( $790 \mu \mathrm{atm}, \mathrm{pH}_{\mathrm{NIST}} 7.9$ and $\sim 490 \mu \mathrm{atm}, \mathrm{pH}_{\mathrm{NIST}} 8.1$ ), three replicate tanks were used; replicate tanks were randomly allocated to treatments. Seawater was pumped from the ocean into the laboratory, filtered to $5 \mu \mathrm{m}$, and stored in four header tanks where it was modified to the desired experimental conditions. Temperature was manipulated through a computer-controlled data logger (CR 1000, Campbell Scientific, Australia). Titanium heating rods in the four header tanks heated the incoming seawater to the set temperatures, which were monitored by the data logger in each header tank and in one aquarium per treatment. The seawater was then pumped into the aquaria at a flow rate of 450-500 $\mathrm{mL} \mathrm{min}^{-1}$ (determined by flow indicators, RS Components, Ltd., UK). Manual temperature and $\mathrm{pH}$ measurements were performed once to twice per day (Table 1), using a Eutech, USA, probe and Oakton, USA, console. For the increased $p \mathrm{CO}_{2}$ treatment, water chemistry was manipulated by bubbling analytical $\mathrm{CO}_{2}$ into the header tanks. The water chemistry was controlled by a computer aquarium system (Aquamedic, Germany), as described in Uthicke et al. (2011) and Vogel and Uthicke (2012). Water samples for total alkalinity $\left(A_{\mathrm{T}}\right)$ and dissolved inorganic carbon (DIC) determinations were taken weekly and analysed by AIMS Laboratory Services (Vindta 3C). The program CO2 SYSCALC.EXE (Lewis and Wallace 1997) was used to calculate carbonate system parameters from $A_{\mathrm{T}}$, DIC, salinity, and temperature values (Table 1).

\section{Experimental approach mimicking 'natural' conditions}

Specimens were kept inside custom made flow-through housings in each aquarium to achieve higher flow conditions more closely mimicking their habitat than in previous experiments (Schmidt et al. 2011; Uthicke et al. 2011; Vogel and Uthicke 2012). Flow-through housings contained two levels made from two standard 6-well cellculturing plates with flow-through lids (Electronic Supplementary Material, ESM Fig. S1). Twenty-four specimens (four specimens per well) of $H$. depressa were put in the lower level and the same number of $M$. vertebralis in the top level. Foraminifera were contained in the housings by placing a plankton mesh $(\varnothing 0.5 \mathrm{~mm}$ : H. depressa, $\varnothing$ $1 \mathrm{~mm}: M$. vertebralis) and additional shading cloth between plate and lid, held tight by rubber bands (ESM Fig. S2). For the construction of the housings, six larger circles $(\varnothing 3.5 \mathrm{~cm})$ were cut into the lids as water outlets and six smaller circles $(\varnothing 0.3 \mathrm{~cm})$ on each side as water inlets. Black plastic tubing was used to space the plates 1 $\mathrm{cm}$ apart and to connect them horizontally and vertically. At the top end, a small aquarium pump delivered a constant flow of water from the aquarium to the inside of the housings. Flow into each well was visible because small flow indicators (1-cm-long red ribbons glued at one end inside each inlet of the housings) were constantly held in place by the flowing water. Flow rates into the individual wells were recorded before and after the experiment, ranging between 180 and $220 \mathrm{~mL} \mathrm{~min}^{-1}$. Velocity of the water flow varied from $4.2-5.2 \times 10^{-1} \mathrm{~m} \mathrm{~s}^{-1}$ at the inlet $\left(\varnothing 0.3 \mathrm{~cm}\right.$ ) to $3.1-3.8 \times 10^{-3} \mathrm{~m} \mathrm{~s}^{-1}$ at the outlet $(\varnothing$ $3.5 \mathrm{~cm})$. The flow rates between inlet and outlet are in the same range as those measured in situ over dead coral rubble (Williams and Carpenter 1998) and sea grass (Cornelisen and Thomas 2009). Both species kept in the flow-through housings appeared to thrive as indicated by healthy colouration, minimal shell breakage, and the development of firm attachment to the walls of the housings by the pseudopodial network. $H$. depressa was attached to the walls of the housings, whereas $M$. vertebralis was attached to the flat bottom of the housings, mimicking its firm attachment and its natural position on sea grass leaves. The flow-through system had the disadvantage that a small number of specimens were lost during the experiment (mean specimen loss per treatment: $H$. depressa: 5-13\%, SD =0-10\%; M. vertebralis 0-6\%, $\mathrm{SD}=0-7 \%)$. 
Table 1 Carbonate system parameters over the course of the experiment

\begin{tabular}{|c|c|c|c|c|c|c|c|}
\hline \multirow[t]{2}{*}{ Treatment } & \multicolumn{4}{|c|}{ Measured parameters } & \multicolumn{3}{|c|}{ Calculated parameters } \\
\hline & $\begin{array}{l}\mathrm{pH}_{\mathrm{NIST}} \\
(\mathrm{SD})\end{array}$ & $\begin{array}{l}\text { Temperature } \\
\left({ }^{\circ} \mathrm{C}\right)(\mathrm{SD})\end{array}$ & $\begin{array}{l}A_{\mathrm{T}} \\
\left(\mu \mathrm{mol} \mathrm{kg}{ }^{-1} \mathrm{SW}\right)\end{array}$ & $\begin{array}{l}\text { DIC } \\
\left(\mu \mathrm{mol} \mathrm{kg}{ }^{-1} \mathrm{SW}\right)\end{array}$ & $\begin{array}{l}p \mathrm{CO}_{2}(\mu \mathrm{atm}) \\
(\mathrm{SD})\end{array}$ & $\begin{array}{l}\Omega_{\mathrm{Ca}} \\
(\mathrm{SD})\end{array}$ & $\begin{array}{l}\Omega_{\mathrm{Ar}} \\
(\mathrm{SD})\end{array}$ \\
\hline $28,8.1$ control & $8.15(0.05)$ & $28.1(0.2)$ & $2332(24)$ & $2031(10)$ & $479(38)$ & $5.1(0.3)$ & $3.4(0.2)$ \\
\hline 31, 8.1 elevated $T$ & $8.14(0.05)$ & $30.8(0.3)$ & $2338(20)$ & $2025(6)$ & $499(32)$ & $5.4(0.3)$ & $3.6(0.2)$ \\
\hline $28,7.9$ elevated $p \mathrm{CO}_{2}$ & $7.98(0.05)$ & $27.9(0.3)$ & $2335(22)$ & 2134 (19) & $738(65)$ & $3.8(0.2)$ & $2.5(0.1)$ \\
\hline $\begin{array}{l}31,7.9 \text { elevated temp \& } \\
{ }_{p} \mathrm{CO}_{2}\end{array}$ & $7.96(0.03)$ & $30.8(0.4)$ & $2337(22)$ & $2142(16)$ & $835(85)$ & $3.8(0.3)$ & $2.6(0.2)$ \\
\hline
\end{tabular}

$\mathrm{pH}$ and temperature values were derived from individual daily measurements $(N=49)$, including light and dark cycle, whereas water chemistry parameters $A_{\mathrm{T}}$ and DIC were measured from two sets of experimental samples taken over the course of the experiment to calculate $p \mathrm{CO}_{2}, \Omega_{\mathrm{Ca}}$ and $\Omega_{\mathrm{Ar}}$

\section{Experimental light levels}

Flow-through housings were made containing two levels so that one species could be kept in the top level exposed to higher light levels than the species in the lower level. Light levels were chosen for each species separately because of their known distributions and different light saturation points determined by pulse amplitude modulation (PAM) fluorometry (Hohenegger 2004; Ziegler and Uthicke 2011; Vogel and Uthicke 2012). PAM fluorometry results for $M$. vertebralis indicated a maximum saturating irradiance $\left(E_{\mathrm{k}}\right)$ between 100 and $140 \mu \mathrm{mol}$ photons $\mathrm{m}^{-2} \mathrm{~s}^{-1}$ and for $H$. depressa between 40 and $60 \mu \mathrm{mol}$ photons $\mathrm{m}^{-2} \mathrm{~s}^{-1}$ (Ziegler and Uthicke 2011). The light levels used in the experiment were chosen to fall below the $E_{\mathrm{k}}$ values by Ziegler and Uthicke (2011) and $P-I$ curve $P_{\max }$ values determined by Vogel and Uthicke (2012) and were selected to correspond to levels which have shown no changes in mortality rates or chlorophyll $a$ concentrations in previous experimental manipulations of the studied species (Schmidt et al. 2011; Uthicke et al. 2011; Vogel and Uthicke 2012; Reymond et al. 2013). H. depressa was put in the lower level $\left(10-17 \mu \mathrm{mol}\right.$ photons $\left.\mathrm{m}^{-2} \mathrm{~s}^{-1}\right)$ of the flow-through housings and $M$. vertebralis in the top level (38-45 $\mu \mathrm{mol}$ photons $\mathrm{m}^{-2} \mathrm{~s}^{-1}$ ) because the latter has a higher $E_{\mathrm{k}}$ point, compared with the diatom-bearing species (Ziegler and Uthicke 2011). Overall, light levels inside the tanks $\left(140-150 \mu \mathrm{mol}\right.$ photons $\left.\mathrm{m}^{-2} \mathrm{~s}^{-1}\right)$ were recorded at the beginning and the end of the experiment using a light quantum sensor (Apogee MQ-200, USA). Light was supplied by $50: 50$ actinic $420 \mathrm{~nm} / 10 \mathrm{~K}$ trichromatic daylight fluorescent grow tubes (Catalina Compact, 12-h dark/12-h light cycle). Green shade cloth (light reduction by $\sim 30 \%$ ) was used for M. vertebralis, and black shade cloth (light reduction by $\sim 50 \%$ ) was used for $H$. depressa. Shade cloth and plankton mesh were exchanged every week to keep light levels constant over the experimental period.
Survivorship and growth

To determine $\%$ survivorship, specimens were examined twice per week and recorded as living, when their cytoplasm exhibited colour, or dead, when the shells and cytoplasm were pale and no cytoplasmic activity was observed (Bernhard 2000). Growth of $H$. depressa and M. vertebralis was expressed as the increase in cross-sectional surface area per day over the experimental period. Procedures of high-resolution photography before and at the end of the experiment were the same as previously published (Uthicke and Altenrath 2010; Schmidt et al. 2011; Vogel and Uthicke 2012). Surface area $\left(\mathrm{mm}^{2}\right)$ of individual Foraminifera was measured and analysed as described in Schmidt et al. (2011). $H$. depressa growth rates have been based on tracking individuals within one well from the beginning to the end of the experiment. This was possible by following distinct shell features and overall size among the images through time. $M$. vertebralis growth rates had to be based on overall means of wells because the shells of this species do not possess characteristic differences that would allow the tracking of individual specimens. Wells where $M$. vertebralis were lost were excluded from the data set, as were wells where mechanical damage to the specimens occurred. Growth rates $\left(\% \mathrm{~d}^{-1}\right)$ were determined following the equation of ter Kuile and Erez (1984). Average initial surface area of analysed specimens did not deviate between treatments both with respect to the mean values and the variance $(H$. depressa: one-way ANOVA, $\quad F_{1,143}=0.29, \quad p=0.8346 ;$ Levene's Test, $F_{3,142}=1.22, p=0.304 ; M$. vertebralis: one-way ANOVA, $F_{1,57}=1.10, p=0.3559$; Levene's Test, $F_{3,53}=1.077$, $p=0.366)$.

Photobiology, oxygen consumption, and chlorophyll $a$ concentration

Photochemical performance of Photosystem II (PSII) was measured by obtaining the maximum quantum yield 
(MQY, dark adapted yield, $F_{\mathrm{v}}: F_{\mathrm{m}}$ ) and the effective quantum yield (EQY, light adapted yield, ФPSII) of individual $H$. depressa and $M$. vertebralis before and at the end of the experiment with an Imaging-PAM Fluorometer (WALZ, Unit IMAG-CM, Maxi Head, Germany; Schmidt et al. 2011; Uthicke et al. 2011; Vogel and Uthicke 2012). Foraminifera were transferred into 6-well plates containing the respective treatment water and dark adapted for $20 \mathrm{~min}$ prior to measuring MQY. Similar light conditions as in the aquaria, supplied by the LED unit of the Maxi head (H. depressa, 10-14 $\mu \mathrm{mol}$ photons $\mathrm{m}^{2} \mathrm{~s}^{-1}$, M. vertebralis 35-40 $\mu \mathrm{mol}$ photons $\mathrm{m}^{2} \mathrm{~s}^{-1}$ ), were used to measure EQY. Calculations of EQY (ФPSII) and MQY $\left(F_{\mathrm{v}}: F_{\mathrm{m}}\right)$ were conducted by the software Imaging Win (WALZ, Germany) after independent AOI (Areas of Interest) were put on the individual Foraminifera from which the measurements were read. For further information on the ImagingPAM, details are described in Hill et al. (2004). Additionally, PAR-absorptivity (Abs) was measured as the ratio of reflectance of red light $(650 \mathrm{~nm}, R)$ to the reflectance of non-absorbed near-infrared light $(780 \mathrm{~nm}$, NIR) from individual Foraminifera at the end of the experiment. This is based on the assumption that the change in photosynthetic pigments within the same species will alter the absorption of red light and change the ratio. For calculating the apparent photosynthetic rate (APR, Ps), we used the formula: Abs $\times \mathrm{EQY} \times$ light intensity (Cooper and Ulstrup 2009). Absorptance measurements are used to calculate APR and are influenced by differences in the calcareous shells of the species. Therefore, affecting absolute and relative differences and are thus only discussed in light of relative changes in response to the tested environmental parameter and not used to compare absolute values between the species.

Respiration and photosynthesis rates were determined in incubation chambers by measuring changes in oxygen concentration during a 15-min dark phase followed by a 15-min light phase, using a custom-build respirometer (Uthicke et al. 2011; Vogel and Uthicke 2012), before and after the experiment. Non-invasive oxygen sensor spots ('optodes', Ø5 mm) were attached to closed glass vials (volume $6.6 \mathrm{~mL}$ ) containing the Foraminifera. Fibre optic cables connected these to an OXY-4 mini transmitter (Presens, Germany). Prior to measurements, specimens were incubated in the dark for a minimum of $25 \mathrm{~min}$ to stabilise temperatures in the flow-through water bath. For photosynthesis measurements, Foraminifera were exposed to the same light conditions as used in the experiment (light sources: Catalina compact: $420 \mathrm{~nm}$ actinic/1,000 K). In each run, one out of four vials did not contain any species, to test for potential respiration not caused by the Foraminifera. Prior to the experiment, baseline respiration and production rates were measured in the ambient $p \mathrm{CO}_{2}$ and temperature treatment. For each of these replicates, prior to and at the end of the experiment, 3 specimens of $M$. vertebralis and 6-8 specimens of $H$. depressa were pooled to obtain a sufficiently strong signal. For final measurements, five replicates were measured per aquarium for $M$. vertebralis and two for $H$. depressa. Respiration rates were normalised to wet weight (determined to $0.01 \mathrm{mg}$ accuracy with balance, Mettler-Toledo), which is known to be highly correlated with dry weight in Foraminifera (Schmidt et al. 2011). Daily net production rates were calculated assuming that the respiration rates reflect a 12-h night cycle and production rates the 12-h day cycle. To determine how the observed changes in photosynthetic performance are linked with pigment content of the whole organism, the average concentration of chlorophyll $a$ was determined at the end of the experiment for a subset (four specimens) per aquaria. Chlorophyll $a$ was extracted and quantified following the protocol described in Schmidt et al. (2011).

\section{Data analysis}

For statistical analyses, MQY $\left(F_{\mathrm{v}}: F_{\mathrm{m}}\right)$, EQY (ФPSII), growth, and survivorship were arc sine transformed because they represent proportions or percentages. Oxygen respiration and production were $\log (x+1)$ transformed and chl $a$ pigment data were log transformed to meet the assumption of the ANOVA. Residual and normality plots on transformed data indicated that assumptions of equal group variance and normality were not violated. Changes in all parameters under the respective temperature and $p \mathrm{CO}_{2}$ treatments were analysed using linear models, into which average temperature and $\mathrm{pH}$ for each individual aquarium obtained through manual measurements were inserted as factors including their interaction term. The analysis of MQY, EQY, and APR was based on average values per well, yielding each a total of 72 values (6 wells $* 4$ treatments $* 3$ replicate tanks). Analysis of respiration parameters was based on two replicate measurements per tank for $H$. depressa $(N=24)$ and four replicate measurements per tank for $M$. vertebralis $(N=48)$. Analysis of chl $a$ content was based on four replicate measurements per tank (4 specimen $* 4$ treatments $* 3$ replicates, $N=48$ ). Analysis of survivorship was based on values for each of the three replicate tanks $(N=3)$. Analysis of growth rates was based on averages per well for $H$. $d e$ pressa $(N=68)$ and for $M$. vertebralis $(N=57)$.

All analyses were conducted in Jmp, Version 10 (SAS 2012). In cases where linear models indicated significant effects in both parameters, or a significant interaction between the stressors, we calculated the expected additive inhibition from each individual parameter according to a standard ecotoxicological model (Bliss 1939) to compare observed effects with expected effects. We determined 
Table 2 Linear model analysis of the effect of all physiological parameters based on values at the end of the experiment with Heterostegina depressa (after 35 days) and Marginopora vertebralis (after 53 days)

\begin{tabular}{|c|c|c|c|c|c|c|c|c|c|c|c|}
\hline \multirow[t]{2}{*}{ Parameter } & \multirow[t]{2}{*}{ Factor } & \multicolumn{5}{|c|}{ Heterostegina depressa } & \multicolumn{5}{|c|}{ Marginopora vertebralis } \\
\hline & & Estimate & SE & $t$ & $p$ & $R^{2}$ & Estimate & SE & $t$ & $p$ & $R^{2}$ \\
\hline \multirow[t]{4}{*}{$\operatorname{MQY}\left(F_{\mathrm{v}}: F_{\mathrm{m}}\right)$} & Intercept & 0.794 & 0.100 & 7.920 & 0.000 & 0.512 & 0.915 & 0.105 & 8.720 & 0.000 & 0.674 \\
\hline & Temp & -0.005 & 0.001 & -7.280 & 0.000 & & -0.009 & 0.001 & -11.420 & 0.000 & \\
\hline & $p \mathrm{CO}_{2}$ & 0.022 & 0.012 & 1.870 & 0.066 & & 0.015 & 0.013 & 1.220 & 0.228 & \\
\hline & Temp $\times p \mathrm{CO}_{2}$ & 0.021 & 0.008 & 2.560 & 0.013 & & 0.013 & 0.009 & 1.510 & 0.135 & \\
\hline \multirow[t]{4}{*}{ EQY (ФPSII) } & Intercept & 2.095 & 0.319 & 6.580 & 0.000 & 0.367 & 1.341 & 0.300 & 4.460 & 0.000 & 0.838 \\
\hline & Temp & -0.025 & 0.002 & -10.530 & 0.000 & & -0.042 & 0.002 & -18.530 & 0.000 & \\
\hline & $p \mathrm{CO}_{2}$ & -0.089 & 0.038 & -2.340 & 0.022 & & 0.039 & 0.036 & 1.080 & 0.286 & \\
\hline & Temp $\times p \mathrm{CO}_{2}$ & -0.077 & 0.027 & -2.900 & 0.005 & & -0.092 & 0.025 & -3.680 & 0.001 & \\
\hline \multirow[t]{4}{*}{ APR (Ps) } & Intercept & 11.594 & 3.398 & 3.410 & 0.001 & 0.851 & 49.862 & 16.798 & 2.970 & 0.004 & 0.781 \\
\hline & Temp & -0.489 & 0.026 & -19.100 & 0.000 & & -1.949 & 0.127 & -15.400 & 0.000 & \\
\hline & $p \mathrm{CO}_{2}$ & 0.931 & 0.404 & 2.300 & 0.025 & & 2.296 & 2.006 & 1.140 & 0.256 & \\
\hline & Temp $\times p \mathrm{CO}_{2}$ & -0.014 & 0.283 & -0.050 & 0.961 & & -1.039 & 1.399 & -0.740 & 0.460 & \\
\hline \multirow[t]{4}{*}{ Respiration } & Intercept & -0.001 & 0.024 & -0.050 & 0.963 & 0.304 & 0.000 & 0.043 & 0.010 & 0.992 & 0.608 \\
\hline & Temp & 0.000 & 0.000 & 2.650 & 0.016 & & 0.002 & 0.000 & 5.960 & 0.000 & \\
\hline & $p \mathrm{CO}_{2}$ & -0.002 & 0.003 & -0.730 & 0.474 & & -0.009 & 0.005 & -1.760 & 0.086 & \\
\hline & Temp $\times p \mathrm{CO}_{2}$ & 0.001 & 0.002 & 0.540 & 0.593 & & -0.012 & 0.004 & -3.440 & 0.001 & \\
\hline \multirow[t]{4}{*}{ Production } & Intercept & 0.037 & 0.135 & 0.270 & 0.788 & 0.587 & 0.150 & 0.136 & 1.110 & 0.274 & 0.399 \\
\hline & Temp & -0.005 & 0.001 & -4.820 & 0.000 & & -0.005 & 0.001 & -4.910 & 0.000 & \\
\hline & $p \mathrm{CO}_{2}$ & 0.016 & 0.016 & 1.000 & 0.329 & & 0.002 & 0.016 & 0.150 & 0.882 & \\
\hline & Temp $\times p \mathrm{CO}_{2}$ & 0.005 & 0.011 & 0.470 & 0.644 & & 0.009 & 0.011 & 0.780 & 0.441 & \\
\hline \multirow[t]{4}{*}{ Net production } & Intercept & 0.038 & 0.146 & 0.260 & 0.796 & 0.592 & 0.162 & 0.148 & 1.090 & 0.282 & 0.521 \\
\hline & Temp & -0.005 & 0.001 & -4.860 & 0.000 & & -0.007 & 0.001 & -6.070 & 0.000 & \\
\hline & $p \mathrm{CO}_{2}$ & 0.018 & 0.017 & 1.040 & 0.313 & & 0.009 & 0.018 & 0.530 & 0.602 & \\
\hline & Temp $\times p \mathrm{CO}_{2}$ & 0.004 & 0.012 & 0.350 & 0.730 & & 0.020 & 0.012 & 1.620 & 0.114 & \\
\hline \multirow[t]{4}{*}{ Chl $\alpha$ content } & Intercept & 2.377 & 2.609 & 0.910 & 0.368 & 0.799 & -11.910 & 5.006 & -2.380 & 0.022 & 0.712 \\
\hline & Temp & -0.233 & 0.020 & -11.880 & 0.000 & & -0.316 & 0.038 & -8.370 & 0.000 & \\
\hline & $p \mathrm{CO}_{2}$ & 0.285 & 0.312 & 0.920 & 0.366 & & 2.334 & 0.595 & 3.930 & 0.000 & \\
\hline & Temp $\times p \mathrm{CO}_{2}$ & 0.620 & 0.219 & 2.840 & 0.007 & & 1.222 & 0.416 & 2.940 & 0.005 & \\
\hline \multirow[t]{4}{*}{ Growth } & Intercept & -3.503 & 1.961 & -1.790 & 0.079 & 0.219 & 0.755 & 0.466 & 1.620 & 0.111 & 0.176 \\
\hline & Temp & -0.044 & 0.015 & -2.960 & 0.004 & & -0.006 & 0.003 & -1.810 & 0.076 & \\
\hline & $p \mathrm{CO}_{2}$ & 0.633 & 0.236 & 2.690 & 0.009 & & -0.060 & 0.054 & -1.110 & 0.270 & \\
\hline & Temp $\times p \mathrm{CO}_{2}$ & 0.161 & 0.133 & 1.210 & 0.228 & & 0.096 & 0.038 & 2.550 & 0.014 & \\
\hline \multirow[t]{4}{*}{ Survivorship } & Intercept & -0.431 & 1.407 & -0.310 & 0.767 & 0.866 & 1.746 & 1.263 & 1.380 & 0.204 & 0.349 \\
\hline & Temp & -0.062 & 0.011 & -5.810 & 0.000 & & -0.019 & 0.010 & -2.040 & 0.075 & \\
\hline & $p \mathrm{CO}_{2}$ & 0.384 & 0.168 & 2.290 & 0.051 & & -0.026 & 0.151 & -0.170 & 0.867 & \\
\hline & Temp $\times p \mathrm{CO}_{2}$ & 0.311 & 0.117 & 2.660 & 0.029 & & 0.018 & 0.105 & 0.170 & 0.867 & \\
\hline
\end{tabular}

Please refer to the method section for data transformations, $R^{2}$ is the overall amount of variance explained by the model, significant effects at the level of $\alpha<0.05$ are in bold

combined effects from fraction changes of the treatments compared with the control $\left(28^{\circ} \mathrm{C}, 479 \mu \mathrm{atm} p \mathrm{CO}_{2}\right)$. Additivity can be presumed when both individual factors are significant, but their interaction is not. In cases where a significant interaction term is present, comparison of the predicted with the observed effect of the combined stressors can reveal if antagonism $(C<A+B)$, or synergism is indicated ( $C>A+B$; Crain et al. 2008).
All experimental data will be made available via www. pangaea.de.

\section{Results}

Daily temperature and $p \mathrm{CO}_{2}$ measurements inside each aquarium are summarised in Table 1. The actual values 


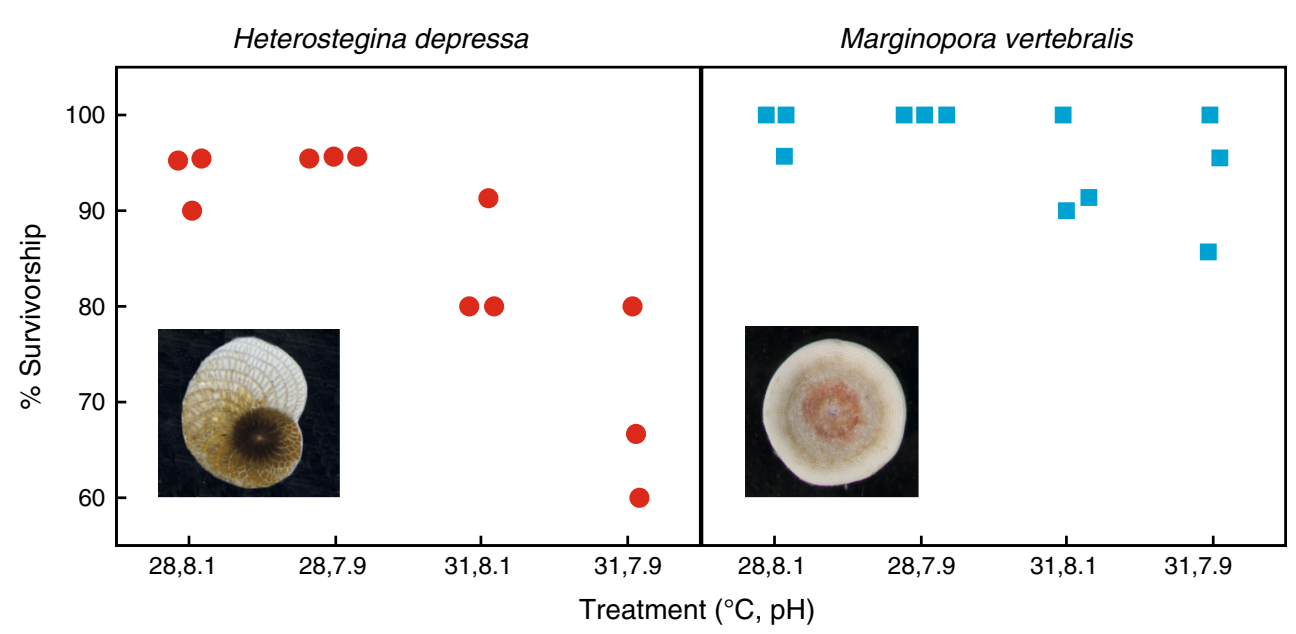

Fig. 1 Survivorship rates (\%) of $H$. depressa (after 35 d) and M. vertebralis (after $53 \mathrm{~d}$ ) at the end of the experiment; data points represent means per aquaria within the treatments. Inset images show representative specimens of $H$. depressa and $M$. vertebralis used in the experiment

represent closely the target values of the treatments. The aragonite $\left(\Omega_{\mathrm{Ar}}\right)$ and calcite $\left(\Omega_{\mathrm{Ca}}\right)$ saturation states in the elevated $p \mathrm{CO}_{2}(\sim 790 \mu \mathrm{atm})$ treatment remained well saturated throughout the experiment, but clearly below that of the 'control' treatment.

Survivorship in $H$. depressa decreased significantly with temperature compared with the controls (Table 2). Survivorship did not decrease with increasing $p \mathrm{CO}_{2}$ (change of $2 \%$ ) and decreased significantly in the combined treatment by $26 \%$ (Fig. 1). Both stressors acted synergistically on survivorship in $H$. depressa because proportional change compared with the controls was more than 3 times higher than the predicted additive effect (Table 3). As a result of the high survivorship in $M$. vertebralis, no effects of any of the treatments or their combination on survivorship were found.

Elevated temperature and $p \mathrm{CO}_{2}$ had a significant negative effect on growth in $H$. depressa (Table 2). Although the interaction term is not significant, it is noteworthy that the lowest growth occurred in the combined treatment (Fig. 2). In the control treatment $\left(28{ }^{\circ} \mathrm{C}, \mathrm{pH} 8.1\right), \mathrm{H}$. depressa grew on average at $0.39 \% \mathrm{~mm}^{2} \mathrm{~d}^{-1}$ which is a factor of five higher than growth rates of $M$. vertebralis, which grew on average at $0.07 \% \mathrm{~mm}^{2} \mathrm{~d}^{-1}$. Elevated temperature and $p \mathrm{CO}_{2}$ alone had no significant effect on growth in $M$. vertebralis but the interaction term was significant (Table 2). The most likely cause for the interaction is a strong increase in growth under elevated $p \mathrm{CO}_{2}$ at $28{ }^{\circ} \mathrm{C}(49 \%)$ whereas all other treatments were similar to the controls.

In $H$. depressa, temperature had a significant negative effect on all of the photophysiological parameters measured (Fig. 3a-f; Table 2), whereas elevated $p \mathrm{CO}_{2}$ had a significant negative effect on APR and a significant positive effect on EQY. In M. vertebralis temperature had a significant negative effect on all three photophysiological parameters whilst elevated $p \mathrm{CO}_{2}$ had no significant effect on either parameter. Significant interactive effects of the treatments have been found in MQY and EQY for $H$. $d e$ pressa and in EQY for $M$. vertebralis (Table 2). The combined effect of the two stressors on EQY was antagonistic, because the observed inhibition in the combined treatment was lower that the predicted combined inhibition.

For both species, daily average net oxygen production rates were positive in all treatments ranging from 0.03 to $0.05 \mu \mathrm{g} \mathrm{O}_{2} \mathrm{~h}^{-1} \mathrm{mg}^{-1}$ (Fig. 3g, h). In both species elevated temperatures reduced oxygen production more than respiration rates $\left(\mu \mathrm{g} \mathrm{O}_{2} \mathrm{~h}^{-1} \mathrm{mg}^{-1}\right.$; Fig. $\left.3 \mathrm{~g}-\mathrm{j}\right)$ whereas elevated $p \mathrm{CO}_{2}$ levels had no significant effect on production or respiration. A significant interaction of $p \mathrm{CO}_{2}$ and temperature was observed for respiration rates in $M$. vertebralis (Table 2). Compared with the control treatment, respiration rates in the elevated temperature treatment were reduced by $19 \%$ and elevated by $6 \%$ in the $\mathrm{pCO}_{2}$ treatment compared with the controls. The highest reduction in respiration rates (46\%) was observed in the combined treatment, explaining the significant interaction term and highlighting the synergistic effect of both stressors on respiration in $M$. vertebralis.

The chl a pigment concentration in $H$. depressa was significantly reduced under elevated temperatures. The interaction with $p \mathrm{CO}_{2}$ was significant as shown by a reduction in the combined treatment by $52 \%$ compared with the controls (Fig. 4). In the elevated temperature treatment it decreased by $41 \%$ and hardly changed $(3 \%)$ in the raised $p \mathrm{CO}_{2}$ treatment. The strongest reduction in chl $a$ content occurred in the combined treatment, suggesting that the combined effect is synergistic. Chlorophyll $a$ pigment content was in the same range in the control 
Table 3 Summary of the significance of individual effects and their interaction based on general linear models given in Table $2(\diamond$ significant, $\bigcirc$ non-significant; $p<0.05$ ) and its interpretation based calculations of predicted additive inhibition and fraction changes compared with the controls

\begin{tabular}{|c|c|c|c|c|c|c|c|c|c|}
\hline \multirow[t]{2}{*}{ Species } & \multirow[t]{2}{*}{ Parameter } & \multicolumn{3}{|c|}{$\begin{array}{l}\text { Summary of general linear } \\
\text { models }\end{array}$} & \multicolumn{3}{|c|}{$\begin{array}{l}\text { Observed inhibition compared with the } \\
\text { control treatment }\end{array}$} & \multirow{2}{*}{$\begin{array}{l}\text { Predicted inhibition (additive) } \\
A+B-\left(A^{*} B\right)\end{array}$} & \multirow[t]{2}{*}{ Combined effect } \\
\hline & & Temp & $p \mathrm{CO}_{2}$ & Interaction & $A:$ Temp & $B: p \mathrm{CO}_{2}$ & $C$ : Interaction & & \\
\hline \multirow{8}{*}{$\begin{array}{l}\text { Heterostegina } \\
\text { depressa }\end{array}$} & MQY & $\diamond$ & - & $\diamond$ & -0.010 & 0.002 & -0.020 & -0.008 & Synergistic \\
\hline & EQY & $\diamond$ & $\diamond$ & $\diamond$ & -0.112 & 0.004 & -0.064 & -0.108 & Antagonistic \\
\hline & APR & $\diamond$ & $\diamond$ & $\bullet$ & -0.246 & -0.012 & -0.270 & -0.260 & Additive \\
\hline & Production & $\diamond$ & $\bullet$ & - & -0.379 & n.a. & n.a. & n.a. & Only temp effect \\
\hline & $\mathrm{Chl} a$ content & $\diamond$ & $\bullet$ & $\diamond$ & -0.414 & 0.032 & -0.517 & -0.368 & Synergistic \\
\hline & Respiration & $\diamond$ & $\bullet$ & $\bullet$ & -0.319 & n.a. & n.a. & n.a. & Only temp effect \\
\hline & Growth & $\diamond$ & $\diamond$ & $\bullet$ & -0.264 & -0.083 & -0.587 & -0.369 & Additive \\
\hline & Survivorship & $\diamond$ & $\bullet$ & $\diamond$ & -0.105 & 0.022 & -0.264 & -0.081 & Synergistic \\
\hline \multirow{8}{*}{$\begin{array}{l}\text { Marginopora } \\
\text { vertebralis }\end{array}$} & MQY & $\diamond$ & $\bullet$ & $\bullet$ & -0.023 & n.a. & n.a. & n.a. & Only temp effect \\
\hline & EQY & $\diamond$ & $\bullet$ & $\diamond$ & -0.273 & -0.042 & -0.235 & -0.327 & Antagonistic \\
\hline & APR & $\diamond$ & • & $\bullet$ & -0.412 & n.a. & n.a. & n.a. & Only temp effect \\
\hline & Production & $\diamond$ & $\bullet$ & $\bullet$ & -0.436 & n.a. & n.a. & n.a. & Only temp effect \\
\hline & $\mathrm{Chl} a$ content & $\diamond$ & $\diamond$ & $\diamond$ & -0.406 & 0.080 & -0.724 & -0.294 & Synergistic \\
\hline & Respiration & $\diamond$ & $\bullet$ & $\diamond$ & -0.187 & 0.060 & -0.463 & -0.115 & Synergistic \\
\hline & Growth & $\bullet$ & $\bullet$ & $\diamond$ & 0.079 & 0.489 & -0.140 & 0.529 & Synergistic \\
\hline & Survivorship & $\bullet$ & $\bullet$ & $\bullet$ & n.a. & n.a. & n.a. & n.a. & No sign. effect \\
\hline
\end{tabular}

n.a. denotes cases where only a single factor and not the interaction term were significant

treatments before and after the experiment with initial concentrations of $0.13(\mathrm{SD}=0.03) \mu \mathrm{g} \mathrm{mg}^{-1}$ wet weight and final $0.16(\mathrm{SD}=0.03) \mu \mathrm{g} \mathrm{mg}^{-1}$ wet weight in $H$. depressa and initial $0.12(\mathrm{SD}=0.008) \mu \mathrm{g} \mathrm{mg}^{-1}$ wet weight final $0.15(\mathrm{SD}=0.02) \mu \mathrm{g} \mathrm{mg}^{-1}$ wet weight in $M$. vertebralis. This indicates that symbiont bleaching did not occur in the control treatments.

Temperature, $p \mathrm{CO}_{2}$, and their interaction had significant effects on the chl $a$ content in M. vertebralis (Table 2). Compared with the control treatment, chl $a$ content in the temperature treatment was reduced by $41 \%$. In the $p \mathrm{CO}_{2}$ treatment chl $a$ content was elevated by $8 \%$ compared with the controls. Despite the apparent positive effect of $p \mathrm{CO}_{2}$ alone, the highest reduction (72\%) was observed in the combined treatment, suggesting a synergistic effect of the stressors on this variable.

In summary, due to temperature elevation, $100 \%$ of the parameters in $H$. depressa and $75 \%$ of parameters in $M$. vertebralis were reduced compared with the controls (Table 3). Elevated $p \mathrm{CO}_{2}$ alone had a significant negative effect on $13 \%$ of the parameters among both species but in combination with temperature, $50 \%$ of all measured parameters showed significant negative effects (Table 3 ).

The strongest reductions in the studied parameters were observed in the treatments where the two stressors acted in combination. An interaction term was statistically significant in half of the measured parameters (Table 2). Of these,
$75 \%$ showed a synergistic interaction between the two stressors whereas the remaining $25 \%$ of the interactions were antagonistic (Table 3).

\section{Discussion}

Photosynthesis, respiration, and chlorophyll $a$ content

Elevated levels of temperature had a significant effect on all photosynthetic parameters, which is consistent with results of previous studies of temperature-induced bleaching in benthic Foraminifera (Schmidt et al. 2011; Uthicke et al. 2011). Temperatures above $30{ }^{\circ} \mathrm{C}$ appear to lead to damage on the protein level in the holobiont and reduce carbon fixation rates of the symbionts due to reduced expression of the RuBisCO enzyme (Doo et al. 2012). In contrast to the strong effect of temperature, elevated levels of $p \mathrm{CO}_{2}$ had mixed influences on photosynthetic parameters (Table 3). Negative effects of elevated $p \mathrm{CO}_{2}$ on photosynthetic rates of Symbiodinium are known to occur at high $p \mathrm{CO}_{2}$ levels, but at intermediate levels, $p \mathrm{CO}_{2}$, even in combination with raised temperature, induced an increase in symbiont oxygen production in Acropora intermedia (Anthony et al. 2008).

In our experiment, oxygen production and dark respiration rates were negatively affected by temperature. 


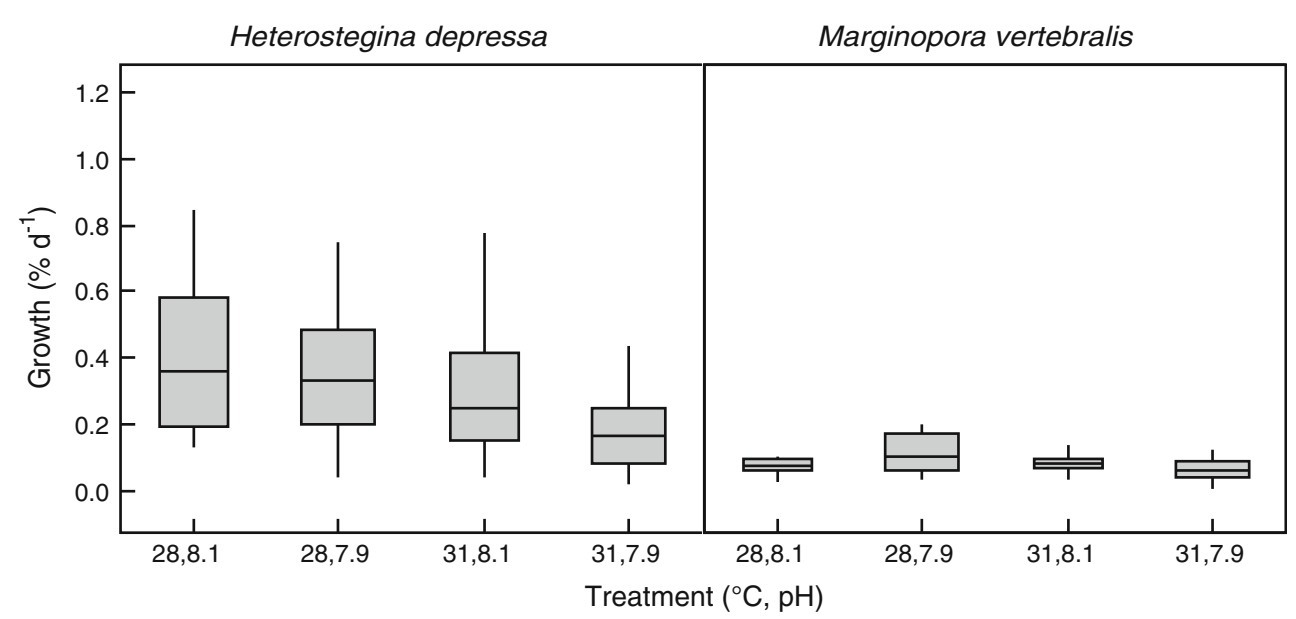

Fig. 2 Growth rates (\% surface area increase $\mathrm{d}^{-1}$ ) of $H$. depressa and $M$. vertebralis during the exposure to experimental conditions for a period of 35 and $53 \mathrm{~d}$, respectively. Data are represented as box-andwhisker plots, the top and bottom of the box (3rd and 1st quartile), the

Previous work suggested that respiration rates in $M$. vertebralis increases with increasing temperatures before and after exposure to $31{ }^{\circ} \mathrm{C}$ for several weeks (Uthicke et al. 2011). Despite the fact that an increase in temperature speeds up enzymatic reactions, explaining increased respiration rates in the short term, in the long term, a decline in respiration rates was observed. This shows that the holobiont was weakened in the $31{ }^{\circ} \mathrm{C}$ compared with the controls at the end of the experiment. Studies on corals also report reduced respiration rates with increasing temperature (Faxneld et al. 2011; Agostini et al. 2013).

We did not observe any effect of raised $p \mathrm{CO}_{2}$ alone on oxygen production and dark respiration. The result that dark respiration was not affected by $p \mathrm{CO}_{2}$ increase alone, is similar to studies in corals (Langdon et al. 2003; Reynaud et al. 2003). However, our results imply a significant synergistic interaction of the two stressors on the reduction of respiration rates in $M$. vertebralis. The synergistic inhibition of respiration observed in the combined treatment indicates that the metabolic rate of the holobiont is reduced, and this effect may propagate into other vital parameters.

Elevated $p \mathrm{CO}_{2}$ alone increased the amount of chl $a$ in $M$. vertebralis but not in $H$. depressa. $\mathrm{CO}_{2}$ fertilisation is known to increase cell numbers, pigments, and productivity in marine unicellular plankton, for example cyanobacteria (Riebesell et al. 1993) and diatoms (Yang and Gao 2012). Productivity increase due to $p \mathrm{CO}_{2}$ increase has also been demonstrated in imperforate Foraminifera (Uthicke and Fabricius 2012) and cell counts of dinoflagellate symbionts in $M$. rossi showed higher symbiont density under elevated $p \mathrm{CO}_{2}$ (Reymond et al. 2013). It is therefore likely that the increased chl $a$ content in M. vertebralis with 2nd quartile (median), the lines extending from the box (whiskers) extend to the outermost data that fall within the distance computed as follows: 3 rd quartile $+1.5^{*}$ (interquartile range); 1 st quartile $-1.5 *$ (interquartile range)

$p \mathrm{CO}_{2}$ enhancement in our study reflects higher photosymbiont density. When Foraminifera were simultaneously exposed to elevated temperature, chlorophyll $a$ content did decrease significantly, indicating that the hypothesised increase in photosymbiont density due to $p \mathrm{CO}_{2}$ fertilisation was counteracted by temperature, leading to trade-offs in the photosymbiont efficiency and density.

Survivorship and growth

Elevated temperature reduced survivorship in $H$. depressa but did not affect $M$. vertebralis, indicating that the latter species is more tolerant. Previous work on the temperature response of $M$. vertebralis also showed no effect on survivorship rate under exposure at $31{ }^{\circ} \mathrm{C}$ for several months, but reported reduced growth at this temperature (Uthicke et al. 2011). Elevated $p \mathrm{CO}_{2}$ did not influence survivorship in either species, which is similar to previous laboratory studies that reported no significant effect of $p \mathrm{CO}_{2}$ elevation on survivorship in several Foraminifera species (Vogel and Uthicke 2012; McIntyre-Wressnig et al. 2013). However, in $H$. depressa the combined effect of $p \mathrm{CO}_{2}$ and temperature on survivorship was significant and synergistic indicating that this species is especially vulnerable to the combination of stressors.

In our experiment, temperature and elevated $p \mathrm{CO}_{2}$ $(738 \mu \mathrm{atm})$ in isolation reduced growth in the hyaline species $H$. depressa. In contrast, Vogel and Uthicke (2012) did not report negative effects on growth in $H$. depressa up to $p \mathrm{CO}_{2}$ levels of $1,600 \mu \mathrm{atm}$. The reason for these differences is not clear but we note that in our experiment the growth rate of $H$. depressa was higher by almost a factor of two than in the experiments by Vogel and Uthicke (2012). 


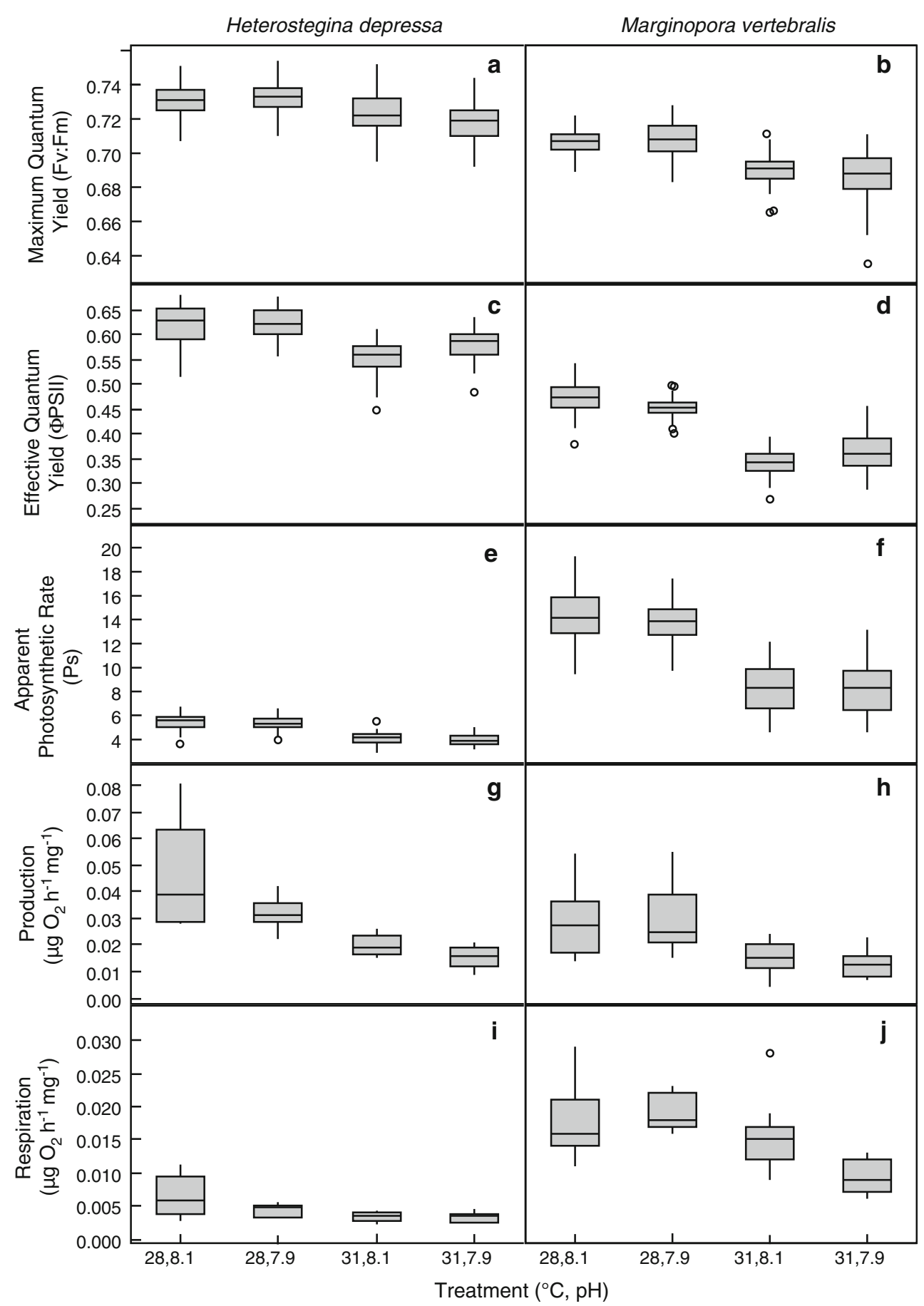

Fig. 3 a-f Photo-physiological parameters of $H$. depressa (after $35 \mathrm{~d}$ ) and $M$. vertebralis (after $53 \mathrm{~d}$ ) expressed as maximum quantum yield (MQY, $F_{\mathrm{v}}: F_{\mathrm{m}}$ ), effective quantum yield (EQY, ФPSII), and apparent photosynthetic rate (Ps); $\mathbf{g}, \mathbf{h}$ oxygen production

It is possible that more flow in our system caused higher growth rates in $H$. depressa, leading to significant differences between control and $p \mathrm{CO}_{2}$ treatments in this species (Table 2). Although we have measured growth as an increase in cell volume, it is likely that in both organisms, growth rate is linked with calcification. In this context, we (photosynthesis) and $\mathbf{i}, \mathbf{j}$ oxygen consumption rates (dark respiration; $\mu \mathrm{g} \mathrm{O}_{2} \mathrm{~h}^{-1} \mathrm{mg}^{-1}$ ) after exposure to experimental conditions. Explainations of box and whisker plots are given in Fig. 2, circles present outliers

note that flow rates as applied here may have led to a thinning of boundary layers on the surface of the Foraminifera, which may have influenced the scale of local changes of $\mathrm{pH}$ induced by photosynthesis and calcification (Glas et al. 2012). A positive influence of water motion on growth rate has been demonstrated in two earlier studies 


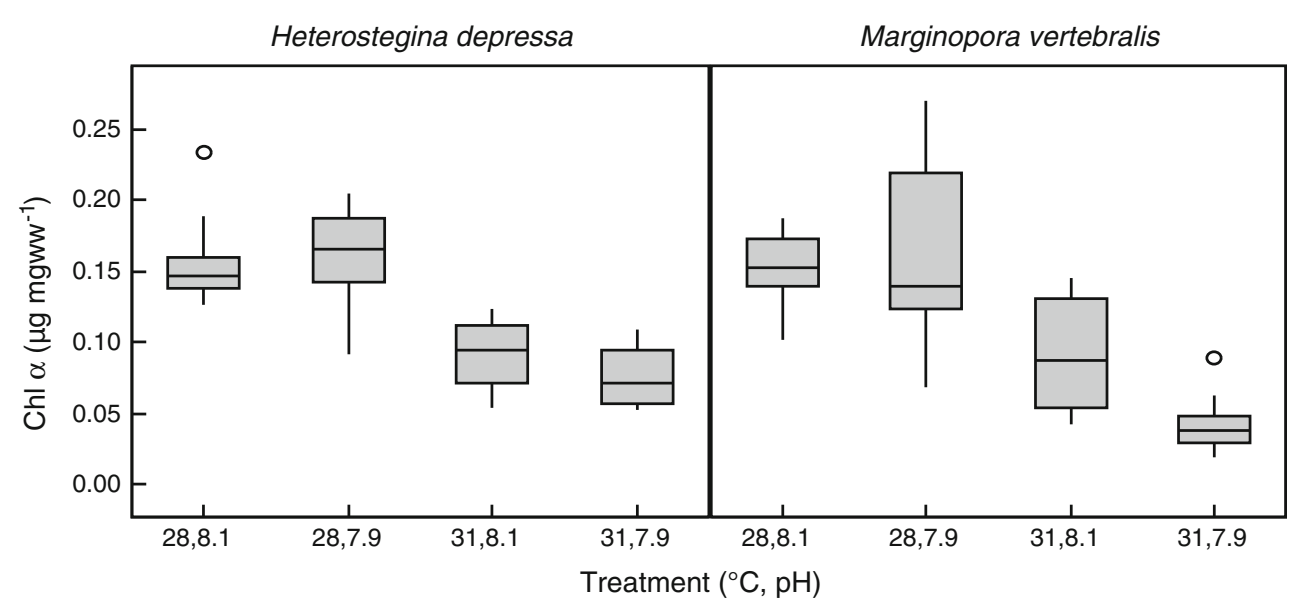

Fig. 4 Chlorophyll $a$ content $\left(\mu \mathrm{g} \mathrm{mg} \mathrm{wet} \mathrm{weight}{ }^{-1}\right)$ at the end of the experiment in H. depressa $(35 \mathrm{~d})$ and M. vertebralis (53 d) after exposure to experimental conditions, box and whisker plots are explained in Fig. 2, circles represent outliers

(ter Kuile and Erez 1984; Hallock et al. 1986). On the other hand, the response of growth and calcification in benthic Foraminifera may be decoupled with respect to the effect of $p \mathrm{CO}_{2}$ and the reaction might be species specific. For example, Amphistegina gibbosa did not exhibit negative effects on growth of up to 2,000 $\mu \mathrm{atm} p \mathrm{CO}_{2}$, but showed patchy test dissolution (McIntyre-Wressnig et al. 2013). Elevated calcification rates were observed under intermediate $p \mathrm{CO}_{2}$ levels $(580-770 \mu \mathrm{atm})$ for the clonal population of Baculogypsina sphaerulata, whereas the second hyaline species in the same study Calcarina gaudichaudii, showed an inconsistent reaction (Fujita et al. 2011). Furthermore, genotype-specific responses to ocean acidification have been reported for other marine organisms, such as coccolithophorids (Langer et al. 2009) and diatoms (Kremp et al. 2012).

In contrast, the porcelanous $M$. vertebralis showed no significant growth response to elevated temperature and $p \mathrm{CO}_{2}$ alone. For this species, growth rates in this study were in the same range as in the previous lower-flow setup (Uthicke et al. 2011; Vogel and Uthicke 2012). A small but not significant increase in growth was observed in $M$. vertebralis in the treatment exposed to elevated $p \mathrm{CO}_{2}$ (738 $\mu \mathrm{atm})$ at $28^{\circ} \mathrm{C}$. A slight growth enhancement was observed in other porcelaneous species (Vogel and Uthicke 2012), whereas other studies reported reduced growth at medium to high $p \mathrm{CO}_{2}$ levels $(700-1,100 \mu \mathrm{atm})$ in $\mathrm{Am}$ phisorus hemprichii (Fujita et al. 2011; Hikami et al. 2011) and $M$. rossii (Reymond et al. 2013).

Differences in the growth and calcification responses to pCO2 enhancement are known between and within taxonomic groups (Ries et al. 2009). Varying responses in calcification processes under intermediate scenarios of up to $900 \mu \mathrm{atm}$ may reflect differential development of protective layers around the precipitated biomineral and different abilities to regulate the $\mathrm{pH}$ at the site of calcification
(Ries et al. 2009). In our experiment, the moderately elevated $p \mathrm{CO}_{2}$ level acting alone may have released the photosymbiont population of $M$. vertebralis from $\mathrm{CO}_{2}$ limitation (Allemand et al. 2004), which would increase carbon translocation to the host and lead to a growth enhancement.

In all treatments in our study, the $\Omega_{\mathrm{Ca}}$ of the seawater remained above two (Table 1) and no test dissolution was observed in any of the treatments. Typically, test dissolution is observed in benthic Foraminifera exposed to much higher $p \mathrm{CO}_{2}$ conditions $(2,000 \mu \mathrm{atm})$ and at much lower $\Omega_{\mathrm{Ar}}$ and $\Omega_{\mathrm{Ca}}$ of sea water than in our experiment (Haynert et al. 2011; McIntyre-Wressnig et al. 2013), although at natural $\mathrm{CO}_{2}$ vents, dissolution was observed already at $\mathrm{pH}$ $\sim 7.9$ (Uthicke et al. 2013). Test dissolution at $p \mathrm{CO}_{2}$ levels equivalent to a $\mathrm{pH}$ of 7.4-7.9 was also observed in $M$. vertebralis in laboratory culture (Sinutok et al. 2011), but specimens in the control treatment in that study also showed slight test dissolution; indicating that the cultured Foraminifera were not physiologically fit.

In summary, our results indicate that, at least in the short term, coral reef Foraminifera are likely to continue to grow under conditions predicted for the end of the century. However, the fact that in both studied species, growth was inhibited in the combined treatment indicates that in the long term, growth and by inference calcification under lower saturation may become more difficult. This may ultimately lead to ecological exclusion of these species as observed at present in $\mathrm{CO}_{2}$ seep systems (Dias et al. 2010; Uthicke and Fabricius 2012; Uthicke et al. 2013).

Combined effects of key global change stressors

Significant interactive effects between $p \mathrm{CO}_{2}$ and warming were observed for $50 \%$ of the parameters investigated. In $75 \%$ of these, for each species, the combined effects were 
synergistic - the effects of warming and elevated $p \mathrm{CO}_{2}$ led to a stronger physiological response than the sum of the effects of the individual parameters (Table 3). Because temperature and $p \mathrm{CO}_{2}$ may affect the holobiont as a whole, it is difficult to offer a physiological explanation for the prevalence of the synergistic effects. As a likely explanation, we suggest that the enhanced negative effects of multiple stressors could reflect trade-offs in resource allocation, where the costs of counteracting the effect of one stressor reduce the ability to counteract the effects of the additional stressor. Similarly, it has been suggested that under stressful environmental conditions, such as elevated inorganic nutrient levels, the pressure on the holobiont to control the population size of its photosymbionts might increase, reducing the capacity of the holobiont to respond to stress (Uthicke et al. 2011). The stress caused by overgrowing population of photosymbionts has been described by Wooldridge (2009) to physiologically affect corals and lower their bleaching thresholds. Furthermore, a 3-yr field experiment demonstrated the same effect, where corals bleached more in artificial nutrient enrichment treatments (Vega Thurber et al. 2013).

Interactive negative effects between $p \mathrm{CO}_{2}$ and temperature have been shown to affect the calcification rate in corals, but the response of the corals was highly species specific (Edmunds et al. 2012). In an experiment increasing nutrient levels and elevating $p \mathrm{CO}_{2}$, photosymbiont concentration in $M$. rossi was reduced more under the combined stress than when individual stressors acted in isolation (Reymond et al. 2013). van Dam et al. (2012) showed that populations of Foraminifera exposed to the herbicide Diuron become disproportionately more sensitive to temperature and both factors acted additively on the foraminiferal photosynthetic response. Ecotoxicological studies on the interaction of climate change with additional stressors, such as pesticide exposure, indicate a prevalence of synergistic interactions across different organisms (Holmstrup et al. 2010; Kohler and Triebskorn 2013). In this respect, the observation on the numerous synergistic interactions in our study indicates that the physiology of the unicellular Foraminifera and/or their symbiosis with algae may be affected in a similar way as that of other organisms, contrary to the hypothesis by Pörtner (2002) that protists are less vulnerable to the studied stressors.

Irrespective of the exact mechanism responsible for the existence of strong synergistic effects between the key global change stressors tested in this study, our results indicate that the effects of environmental change in the shallow marine realm under expected $\mathrm{CO}_{2}$ emission scenarios are likely to be underestimated when the effects of elevated $p \mathrm{CO}_{2}$ and temperature are investigated in isolation.
Acknowledgments The study was funded by the Australian Institute of Marine Science and conducted with the support of funding from the Australian Government's National Environmental Research Program. We are grateful for the assistance of M. Takahashi for developing the design and constructions of the flow-through housings. J. Brandt assisted with digital image analysis. The study benefited greatly for the help of F. Flores, S. Noonan, N. Webster, and A. Negri.

Open Access This article is distributed under the terms of the Creative Commons Attribution License which permits any use, distribution, and reproduction in any medium, provided the original author(s) and the source are credited.

\section{References}

Agostini S, Fujimura H, Higuchi T, Yuyama I, Casareto BE, Suzuki Y, Nakano Y (2013) The effects of thermal and high-CO2 stresses on the metabolism and surrounding microenvironment of the coral Galaxea fascicularis. C R Biol 336:384-391

Allemand D, Ferrier-Pagès C, Furla $\mathrm{P}$, Houlbrèque F, Puverel S, Reynaud S, Tambutté É, Tambutté S, Zoccola D (2004) Biomineralisation in reef-building corals: from molecular mechanisms to environmental control. C R Palevol 3:453-467

Anthony KRN, Kline DI, Diaz-Pulido G, Dove S, Hoegh-Guldberg O (2008) Ocean acidification causes bleaching and productivity loss in coral reef builders. Proc Natl Acad Sci U S A 105: 17442-17446

Arieli RN, Almogi-Labin A, Abramovich S, Herut B (2011) The effect of thermal pollution on benthic foraminiferal assemblages in the Mediterranean shoreface adjacent to Hadera power plant (Israel). Mar Pollut Bull 62:1002-1012

Bernhard JM (2000) Distinguishing live from dead foraminifera: Methods review and proper applications. Micropaleontology 46:38-46

Blackmon PD, Todd R (1959) Mineralogy of some foraminifera as related to their classification and ecology. J Paleontol 1-15

Bliss CI (1939) The toxicity of poisons applied jointly. Ann Appl Biol 26:585-615

Cooper TF, Ulstrup KE (2009) Mesoscale variation in the photophysiology of the reef building coral Pocillopora damicornis along an environmental gradient. Estuar Coast Shelf Sci 83:186-196

Cornelisen CD, Thomas FIM (2009) Prediction and validation of flow-dependent uptake of ammonium over a seagrass-hardbottom community in Florida Bay. Mar Ecol Prog Ser 386:71-81

Crain CM, Kroeker K, Halpern BS (2008) Interactive and cumulative effects of multiple human stressors in marine systems. Ecol Lett 11:1304-1315

Dias BB, Hart B, Smart CW, Hall-Spencer JM (2010) Modern seawater acidification: the response of foraminifera to high- $\mathrm{CO}_{2}$ conditions in the Mediterranean Sea. J Geol Soc London 167:843-846

Doo SS, Mayfield AB, Byrne M, Chen HK, Nguyen HD, Fan TY (2012) Reduced expression of the rate-limiting carbon fixation enzyme RuBisCO in the benthic foraminifer Baculogypsina sphaerulata holobiont in response to heat shock. J Exp Mar Biol Ecol 430:63-67

Edmunds PJ, Brown D, Moriarty V (2012) Interactive effects of ocean acidification and temperature on two scleractinian corals from Moorea, French Polynesia. Glob Chang Biol 18:2173-2183

Fabricius KE, Langdon C, Uthicke S, Humphrey C, Noonan S, De'ath G, Okazaki R, Muehllehner N, Glas MS, Lough JM (2011) 
Losers and winners in coral reefs acclimatized to elevated carbon dioxide concentrations. Nat Clim Chang 1:165-169

Faxneld S, Jorgensen TL, Nguyen ND, Nystrom M, Tedengren M (2011) Differences in physiological response to increased seawater temperature in nearshore and offshore corals in northern Vietnam. Mar Environ Res 71:225-233

Fujita K, Hikami M, Suzuki A, Kuroyanagi A, Sakai K, Kawahata H, Nojiri Y (2011) Effects of ocean acidification on calcification of symbiont-bearing reef foraminifers. Biogeosciences 8:2089-2098

Glas MS, Fabricius KE, de Beer D, Uthicke S (2012) The $\mathrm{O}_{2}, \mathrm{pH}$ and $\mathrm{Ca}^{2+}$ Microenvironment of Benthic Foraminifera in a High $\mathrm{CO}_{2}$ World. PLoS One 7:e50010

Hallock P (1985) Why are larger foraminifera large? Paleobiology 11:195-208

Hallock P, Talge HK (1993) Symbiont loss ("bleaching") in the reefdwelling benthic foraminifera Amphistegina gibbosa in the Florida Keys in 1991-92. Proceedings of the Colloquium on Global Aspects of Coral Reefs: Health, Hazards and History, Rosenstiel School of Marine and Atmospheric Science, University of Miami, pp 94-100

Hallock P, Forward LB, Hansen HJ (1986) Influence of environment on the test shape of Amphistegina. J Foraminiferal Res $16: 224-231$

Hallock P, Talge HK, Smith KM, Cockey EM (1992) Bleaching in the reef-dwelling foraminifera Amphistegina gibbosa. Proc 7th Int Coral Reef Symp 1:44-49

Haynert K, Schonfeld J, Riebesell U, Polovodova I (2011) Biometry and dissolution features of the benthic foraminifer Ammonia aomoriensis at high $p \mathrm{CO}_{2}$. Mar Ecol Prog Ser 432:53-67

Hikami M, Ushie H, Irie T, Fujita K, Kuroyanagi A, Sakai K, Nojiri Y, Suzuki A, Kawahata H (2011) Contrasting calcification responses to ocean acidification between two reef foraminifers harboring different algal symbionts. Geophys Res Lett 38

Hill R, Schreiber U, Gademann R, Larkum AWD, Kuhl M, Ralph PJ (2004) Spatial heterogeneity of photosynthesis and the effect of temperature-induced bleaching conditions in three species of corals. Mar Biol 144:633-640

Hoegh-Guldberg O, Mumby PJ, Hooten AJ, Steneck RS, Greenfield P, Gomez E, Harvell CD, Sale PF, Edwards AJ, Caldeira K, Knowlton N, Eakin CM, Iglesias-Prieto R, Muthiga N, Bradbury RH, Dubi A, Hatziolos ME (2007) Coral reefs under rapid climate change and ocean acidification. Science 318:1737-1742

Hohenegger J (2004) Depth coenoclines and environmental considerations of western pacific larger Foraminifera. J Foraminiferal Res 34:9-33

Hohenegger J, Yordanova E, Nakano Y, Tatzreiter F (1999) Habitats of larger foraminifera on the upper reef slope of Sesoko Island, Okinawa, Japan. Mar Micropaleontol 36:109-168

Holmstrup M, Bindesbøl A, Oostingh GJ, Duschl A, Scheil V, Köhler H, Loureiro S, Soares AMVM, Ferreira ALG, Kienle C, Gerhardt A, Laskowski R, Kramarz PE, Bayley M, Svendsen C, Spurgeon DJ (2010) Interactions between effects of environmental chemicals and natural stressors: A review. Sci Total Environ 408:3746-3762

Koch M, Bowes G, Ross C, Zhang XH (2013) Climate change and ocean acidification effects on seagrasses and marine macroalgae. Glob Chang Biol 19:103-132

Kohler HR, Triebskorn R (2013) Wildlife Ecotoxicology of Pesticides: Can We Track Effects to the Population Level and Beyond? Science 341:759-765

Kremp A, Godhe A, Egardt J, Dupont S, Suikkanen S, Casabianca S, Penna A (2012) Intraspecific variability in the response of bloom-forming marine microalgae to changed climate conditions. Ecol Evol 2:1195-1207

Kuroyanagi A, Kawahata H, Suzuki A, Fujita K, Irie T (2009) Impacts of ocean acidification on large benthic foraminifers:
Results from laboratory experiments. Mar Micropaleontol 73: 190-195

Langdon C, Broecker WS, Hammond DE, Glenn E, Fitzsimmons K, Nelson SG, Peng TH, Hajdas I, Bonani G (2003) Effect of elevated $\mathrm{CO} 2$ on the community metabolism of an experimental coral reef. Global Biogeochem Cycles 17

Langer G, Nehrke G, Probert I, Ly J, Ziveri P (2009) Strain-specific responses of Emiliania huxleyi to changing seawater carbonate chemistry. Biogeosciences 6:2637-2646

Langer MR, Lipps JH (2003) Foraminiferal distribution and diversity, Madang Reef and Lagoon, Papua New Guinea. Coral Reefs 22: $143-154$

Langer MR, Silk MT, Lipps JH (1997) Global ocean carbonate and carbon dioxide production; the role of reef Foraminifera. J Foraminiferal Res 27:271-277

Lee JJ (1995) Living Sands - The symbiosis of protists and their algae can provide good models for the study of host/symbiont interactions. Bioscience 45:252-261

Lee JJ (2006) Algal symbiosis in larger foraminifera. Symbiosis 42:63-75

Lee JJ, Hallock P (1987) Algal symbiosis as the driving force in the evolution of larger Foraminifera. Ann N Y Acad Sci 503: 330-347

Lee JJ, McEnergy ME, Röttger R, Reimer CW (1980) The isolation, culture and identification of endosymbiotic diatoms from Heterostegina depressa D'Orbigny and Amphistegina lessonii D’Orbigny (Larger Foraminifer) from Hawaii. Botanica Marina 23:297-302

Leutenegger S (1984) Symbiosis in benthic Foraminifera: specificity and host adaptations. J Foraminiferal Res 14:16-35

Lewis E, Wallace D (1997) CO2 System Calculations Software CO2SYSTM.EXE. Global Ocean Data Analysis centre

Lough JM, Hobday AJ (2011) Observed climate change in Australian marine and freshwater environments. Mar Freshw Res 62:984-999

Martin S, Gattuso JP (2009) Response of Mediterranean coralline algae to ocean acidification and elevated temperature. Glob Chang Biol 15:2089-2100

McCulloch M, Falter J, Trotter J, Montagna P (2012) Coral resilience to ocean acidification and global warming through $\mathrm{pH}$ upregulation. Nat Clim Chang 2:623-633

McIntyre-Wressnig A, Bernhard JM, McCorkle DC, Hallock P (2013) Non-lethal effects of ocean acidification on the symbiont-bearing benthic foraminifer Amphistegina gibbosa. Mar Ecol Prog Ser 472:45-60

Momigliano P, Uthicke S (2013) Symbiosis in a giant protist (Marginopora vertebralis, Soritinae): flexibility in symbiotic partnerships along a natural temperature gradient. Mar Ecol Prog Ser 491:33-46

Nobes K, Uthicke S, Henderson R (2008) Is light the limiting factor for the distribution of benthic symbiont bearing foraminifera on the Great Barrier Reef? J Exp Mar Biol Ecol 363:48-57

Pawlowski J, Holzmann M, Berney C, Fahrni J, Gooday AJ, Cedhagen T, Habura A, Bowser SS (2003) The evolution of early Foraminifera. Proc Natl Acad Sci U S A 100:11494-11498

Pochon X, Garcia-Cuetos L, Baker AC, Castella E, Pawlowski J (2007) One-year survey of a single Micronesian reef reveals extraordinarily rich diversity of Symbiodinium types in soritid foraminifera. Coral Reefs 26:867-882

Pörtner HO (2002) Climate variations and the physiological basis of temperature dependent biogeography: systemic to molecular hierarchy of thermal tolerance in animals. Comp Biochem Physiol A Mol Integr Physiol 132:739-761

Pörtner HO (2008) Ecosystem effects of ocean acidification in times of ocean warming: a physiologist's view. Mar Ecol Prog Ser 373:203-217 
Redondo-Rodriguez A, Weeks SJ, Berkelmans R, Hoegh-Guldberg O, Lough JM (2012) Climate variability of the Great Barrier Reef in relation to the tropical Pacific and El Nino-Southern Oscillation. Mar Freshw Res 63:34-47

Renema W (2006) Habitat variables determining the occurrence of large benthic foraminifera in the Berau area (East Kalimantan, Indonesia). Coral Reefs 25:351-359

Reymond CE, Lloyd A, Kline DI, Dove SG, Pandolfi JM (2013) Decline in growth of foraminifer Marginopora rossi under eutrophication and ocean acidification scenarios. Glob Chang Biol 19:291-302

Reynaud S, Leclercq N, Romaine-Lioud S, Ferrier-Pages C, Jaubert J, Gattuso JP (2003) Interacting effects of $\mathrm{CO}_{2}$ partial pressure and temperature on photosynthesis and calcification in a scleractinian coral. Glob Chang Biol 9:1660-1668

Riebesell U, Wolf-Gladrow DA, Smetacek V (1993) Carbon dioxide limitation of marine phytoplankton growth rates. Nature 361: 249-251

Ries JB, Cohen AL, McCorkle DC (2009) Marine calcifiers exhibit mixed responses to $\mathrm{CO}_{2}$-induced ocean acidification. Geology 37:1131-1134

Rodolfo-Metalpa R, Lombardi C, Cocito S, Hall-Spencer JM, Gambi MC (2010) Effects of ocean acidification and high temperatures on the bryozoan Myriapora truncata at natural $\mathrm{CO}_{2}$ vents. Mar Ecol 31:447-456

Rodolfo-Metalpa R, Houlbreque F, Tambutte E, Boisson F, Baggini C, Patti FP, Jeffree R, Fine M, Foggo A, Gattuso JP, HallSpencer JM (2011) Coral and mollusc resistance to ocean acidification adversely affected by warming. Nat Clim Chang $1: 308-312$

SAS (2012) JMP statistics software, Version 10. SAS

Schmidt C, Heinz P, Kucera M, Uthicke S (2011) Temperatureinduced stress leads to bleaching in larger benthic foraminifera hosting endosymbiotic diatoms. Limnol Oceanogr 56:1587-1602

Sinutok S, Hill R, Doblin MA, Wuhrer R, Ralph PJ (2011) Warmer more acidic conditions cause decreased productivity and calcification in subtropical coral reef sediment-dwelling calcifiers. Limnol Oceanogr 56:1200-1212

Talge HK, Hallock P (2003) Ultrastructural responses in fieldbleached and experimentally stressed Amphistegina gibbosa (Class Foraminifera). J Eukaryot Microbiol 50:324-333

ter Kuile B, Erez J (1984) In situ growth rate experiments on the symbiont-bearing foraminifera Amphistegina lobifera and Amphisorus hemprichii. J Foraminiferal Res 14:262-276
Uthicke S, Altenrath C (2010) Water column nutrients control growth and $\mathrm{C}$ : $\mathrm{N}$ ratios of symbiont-bearing benthic foraminifera on the Great Barrier Reef, Australia. Limnol Oceanogr 55:1681-1696

Uthicke S, Fabricius KE (2012) Productivity gains do not compensate for reduced calcification under near-future ocean acidification in the photosynthetic benthic foraminifer species Marginopora vertebralis. Glob Chang Biol 18:2781-2791

Uthicke S, Momigliano P, Fabricius KE (2013) High risk of extinction of benthic foraminifera in this century due to ocean acidification. Sci Rep 3

Uthicke S, Vogel N, Doyle J, Schmidt C, Humphrey C (2011) Interactive effects of climate change and eutrophication on the dinoflagellate-bearing benthic foraminifer Marginopora vertebralis. Coral Reefs: $1-14$

van Dam JW, Negri AP, Mueller JF, Altenburger R, Uthicke S (2012) Additive pressures of elevated sea surface temperatures and herbicides on symbiont-bearing foraminifera. PLoS One 7:e33900

Vega Thurber RL, Burkepile DE, Fuchs C, Shantz AA, McMinds R, Zaneveld JR (2013) Chronic nutrient enrichment increases prevalence and severity of coral disease and bleaching. Glob Chang Biol 20:544-554

Vogel N, Uthicke S (2012) Calcification and photobiology in symbiont-bearing benthic foraminifera and responses to a high $\mathrm{CO}_{2}$ environment. J Exp Mar Biol Ecol 424:15-24

Wernberg T, Smale DA, Thomsen MS (2012) A decade of climate change experiments on marine organisms: procedures, patterns and problems. Glob Chang Biol 18:1491-1498

Wernberg T, Smale DA, Tuya F, Thomsen MS, Langlois TJ, de Bettignies T, Bennett S, Rousseaux CS (2013) An extreme climatic event alters marine ecosystem structure in a global biodiversity hotspot. Nat Clim Chang 3:78-82

Williams SL, Carpenter RC (1998) Effects of unidirectional and oscillatory water flow on nitrogen fixation (acetylene reduction) in coral reef algal turfs, Kaneohe Bay, Hawaii. J Exp Mar Biol Ecol 226:293-316

Wooldridge SA (2009) Water quality and coral bleaching thresholds: Formalising the linkage for the inshore reefs of the Great Barrier Reef, Australia. Mar Pollut Bull 58:745-751

Yang GY, Gao KS (2012) Physiological responses of the marine diatom Thalassiosira pseudonana to increased $p \mathrm{CO}_{2}$ and seawater acidity. Mar Environ Res 79:142-151

Ziegler M, Uthicke S (2011) Photosynthetic plasticity of endosymbionts in larger benthic coral reef Foraminifera. J Exp Mar Biol Ecol 407:70-80 